\title{
SEASONAL PATTERNS IN THE DIVERSITY OF HISTERID BEETLES (HISTERIDAE) ARE ECOSYSTEM SPECIFIC? A CASE IN PARA STATE, NORTHERN BRAZIL
}

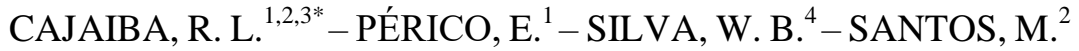 \\ ${ }^{1}$ University of Taquari Valley, Laboratory of Ecology and Evolution, R. AvelinoTallini, 95900- \\ 000, Lajeado, RS, Brazil \\ ${ }^{2}$ Laboratory of Applied Ecology, CITAB - Centre for the Research and Technology of \\ Agro-Environment and Biological Sciences, University of Trás-os-Montes e Alto Douro, \\ 5000-911, Vila Real, Portugal
}

${ }^{3}$ Federal Institute of Education, Science and Technology of Maranhão, R. Dep. Gastão Vieira, 1000, 65393-000, Buriticupu, MA, Brazil

${ }^{4}$ Federal University of Pará, R. Cel. José Porfírio, 2515, 68371-040, Altamira - PA, Brazil

*Corresponding author

e-mail: reinaldocajaiba@hotmail.com

(Received $30^{\text {th }}$ Apr 2017; accepted $11^{\text {th }}$ Aug 2017)

\begin{abstract}
The objective of this work was to characterize the seasonal variation in the community of Histerid beetles (Histeridae) of different ecosystems in the Brazilian Amazon, ranging from primary or secondary forests with different stages of regeneration to cocoa farms and pastures. Pitfall traps were distributed within the monitored ecosystems during different periods of the year. A total of 1945 Histerid beetles, belonging to five genera and 14 species were captured. Higher diversities were observed during the rainy season, although with differences among ecosystems. The genera Phelister and Hister were ubiquitous in all ecosystems, constituting $71 \%$ of all the specimens captured. Histerid beetle communities, discriminated by ordination methods, change gradually from the most conserved ecosystems to more disturbed ones. Moreover, the results showed that disturbed ecosystems, namely cocoa farms and pastures, have detrimental effects on the occurrence of Histerid beetles, which are considered forest specialists, while enhancing generalist species.
\end{abstract}

Keywords: Amazon rainforest, biodiversity, soil insect, fluctuation, tropical forest

\section{Introduction}

Currently, there is enormous concern and speculation about the effects of anthropogenic disturbance on the biodiversity of tropical ecosystems, including the effects on species composition and the modifications in the ecological services provided (e.g. Morris, 2010; Aerts and Honnay, 2011; Cajaiba et al., 2017a). Deforestation in the Neotropics, particularly in the Brazilian Amazon (Amazonia), has been causing a sharp erosion of biodiversity and disruption of the complex global climate phenomena (e.g. Hassan et al., 2005; Morris, 2010). Therefore, the conservation of the Amazonian ecosystems represents a growing core challenge for sustaining earth's functioning and ultimately that of mankind (e.g. Viana and Pinheiro, 1988; Viegas et al., 2014).

Predicting the ecological consequences of land use/land cover (LU/LC) changes is therefore a subject of scientific and political interest in order to support strategic options for sustainable development, land use planning and natural resources management 
(Turner et al., 2007). In this context, ecological assessment and monitoring are important tools to support effective management of ecosystems and natural resources, in which the use of pertinent indicators is crucial for measuring and evaluating the status and trends of target environmental systems (Cajaiba and Silva, 2017).

Ecological integrity is a key concept in natural resource management, and researchers have been trying to improve public understanding of this concept by using simple scientific measures known as ecological indicators (Andreasen et al., 2001). In fact, ecological integrity can be measured and interpreted by changes in abundance, diversity, and composition of groups of indicator organisms that ultimately depend on system resources and conditions. Correlates of integrity in terrestrial landscapes have been proposed, along with many specific indicators that measure various aspects of the ecosystems (Cajaiba and Silva, 2017). Among the various indicators, terrestrial invertebrates, and particularly insects, play a crucial role in most ecological processes, and they are key components of ecosystem structure and functioning (Bicknell et al., 2014; Viegas et al., 2014; Cajaiba and Silva, 2015; Cajaiba et al., 2015; Campos and Hernández, 2015). Insect abundance and richness are related with other taxa, climate, and soil characteristics, thus representing potential target indicators of environmental changes (e.g. Nichols et al., 2008; Cajaiba et al., 2015). Therefore, a better understanding of the ecological relevance of insects in the humid tropics could support decision-making and robust management/recovery of imperilled ecosystems in the scope of the need for rapid, standardised, and cost-effective assessment methodologies (Godfray et al., 1999).

Beetles have characteristics that make them appropriate for ecological studies (Vasquez-Velez et al., 2010; Paoletti et al., 2010; Cajaiba and Silva, 2015) monitoring different compartments of the system (Marinoni, 2001). Among beetles, those of the family Histeridae (Histerid beetles - HB) are known as generalist predators, with wide range of habitats, which may occur in faeces, fungi, tree trunks, decomposing fruit, roots of trees, bird nests, burrows of mammals or reptiles, and in decaying vegetation. In addition, they are important predators of eggs and larvae, particularly of Diptera (Cyclorrhapha). Some groups are related to other animals, particularly social insects such ants and termites (Leivas et al., 2013). Despite its ecological importance, few studies have been conducted in Brazil using this group, and the published ones focused on the systematics (Degallier et al., 2011; Corrêa et al., 2012; Leivas et al., 2012a, b; Leivas et al., 2015).

In the present study, we aimed to characterize the seasonal communities of HB of different ecosystems in the Brazilian Amazon, ranging from primary or secondary forests with different stages of regeneration, to cocoa farms and pastures. These ecosystems, characterized by dissimilar structure and complexity, could be associated with divergent seasonal patterns in richness and diversity. Specifically, we addressed the following questions: 1) does the composition of Histerid beetle communities vary among the different ecosystems and 2) does the diversity of Histeridae assemblies in the Amazon biome differ among seasons?

\section{Material and methods}

\section{Study area}

This study was performed near the city of Uruará, state of Pará, northern Brazil (Fig. 1). The territorial extension of the municipality is $10796 \mathrm{~km}^{2}$ and its population 
encompasses circa 44789 inhabitants. The dominant land use/ land cover (LU/LC) is natural forest (69\% of the area) and deforestation is concentrated mainly in the southcentral part of territory and near the main roads. Extensive livestock production and the exploitation of timber at a large scale (mostly illegal) are currently considered the most serious environmental threats (Cajaiba and Silva, 2017). The studied areas contain the pertinent gradients, in terms of biophysical and ecological characteristics, for testing the response of Histerid beetle communities (Cajaiba and Silva, 2017) facing the main anthropogenic drivers. These gradients encompass: Native Vegetation - NV, Early Secondary succession - ES (vegetation with five years of regeneration), Mature Secondary succession - MS (vegetation with 15 years of regeneration), Agriculture - Ag (cocoa plantations, Theobroma cacao L.) and Pasture for extensive livestock - Pa. The climate of the study area is classified as Aw (Köppen), hot and humid and the average annual rainfall is $2000 \mathrm{~mm}$ (Cajaiba et al., 2017b).

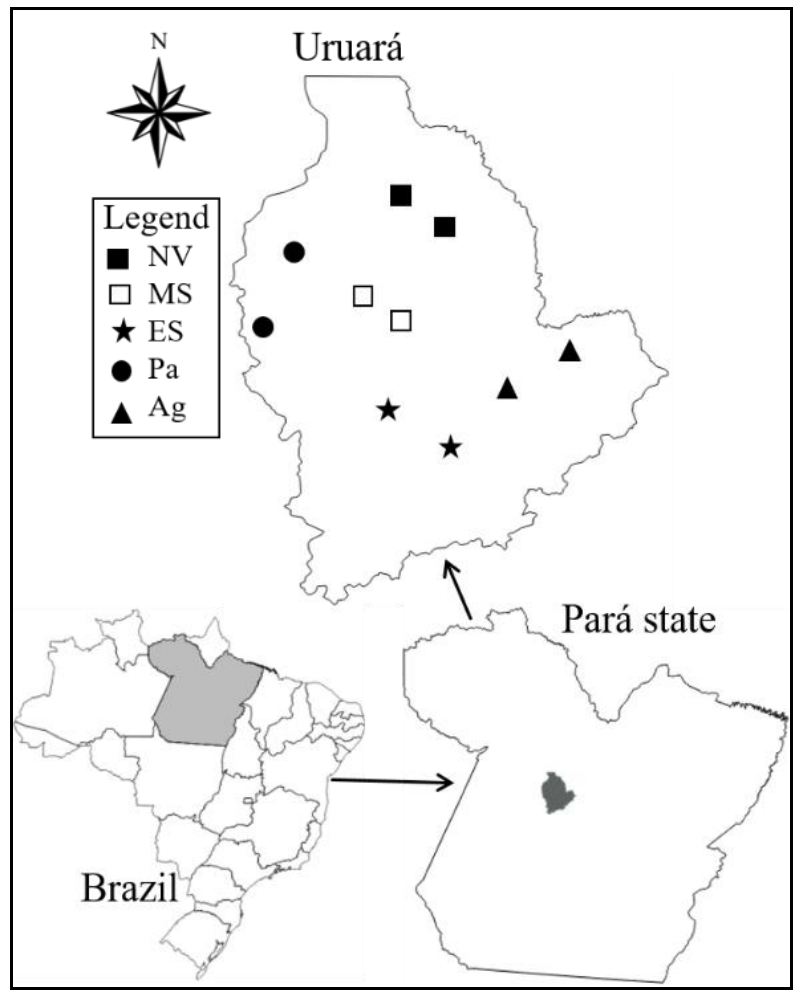

Figure 1. Location of the study region in the municipality of Uruará, state of Pará, northern Brazil. Location of the sampling areas: NV, Native vegetation; MS, Mature secondary succession; ES, Early secondary succession; Ag, Agriculture; Pa, Pasture.

\section{Histerid beetles sampling}

Sampling was carried out during the year 2015, in the months of February/ March (rainy season), June (final of rainy season and early dry season) and September/ October (dry season). This allowed integrating eventual seasonal differences in the diversity of Histerid beetles (HB). The sample points were placed at a minimum distance of 100 meters from ecotones, to ensure that most HB captured were associated to the ecosystem in study. Pitfall traps with $75 \mathrm{~mm}$ diameter and $110 \mathrm{~mm}$ deep were filled with preservative liquid consisting of formalin, alcohol, water and a few drops of 
detergent to break the surface tension. A roof was attached to each trap to prevent rainwater from entering the trap, remaining installed for $48 \mathrm{~h}$ prior to collection. Each pitfall contained different baits such as human faeces, meat and banana in order to attract different species according to their feeding habits (non-baited pitfalls were used as control).

In each studied ecosystem (NV, MS, ES, Ag and Pa) seven sample points were placed $100 \mathrm{~m}$ apart. Each sample point contained four pitfall traps including the different baits (faeces, carrion, banana and non-baited), separated by 5 meters. The distance between pitfall traps allowed individuals to choose their preferential food resource (Almeida and Louzada, 2009). This protocol was applied to all areas and periods of collections, totalizing a sampling effort of 840 traps. In order to complement the pitfall derived information (Cajaiba et al., 2014), specific methods were used to collect leaf litter invertebrates. Ten random sampling points of $1 \mathrm{~m}^{2}$ were selected in each ecosystem and sampling period. At each collection point ('litter-only'), only the loose soil was gently scraped with a metal trowel, to include those HB into the samples that fell out of the leaf litter during this collection procedure. We refrained from simply separating leaf litter and soil, considering that when we remove the litter, HB might flee the litter and hide in the loose topsoil.

\section{Assemblage analysis}

Richness and abundance of HB were measured in each sampling site and differences among ecosystems were gauged using One-Way-Analysis-of-Variance (ANOVA). ANOVA was also applied to find possible differences in HB along the year. When the ANOVA indicated differences in the average among ecosystems and/or seasonality, a Tukey's post-hoc test was performed to find specific difference(s). The normality of the data was verified by the Shapiro-Wilk test.

The taxonomic composition of HB communities between ecosystems was compared using Permutational Multivariate Analysis of Variance (PERMANOVA). Non-metric Multidimensional Scaling (NMDS) plots were used to help interpret the results found with the PERMANOVAs (see Anderson, 2001 for similar procedure). In order to check for environmental variables with influence on the HB communities, associated with periods of the year, a correlation analysis (Pearson correlation) was applied between HB abundance and richness and meteorological data - temperature, humidity and precipitation. All analyses were performed using PAST software version 3.14 (Hammer et al., 2001).

\section{Results}

\section{Composition of Histeridae}

A total of 1945 individuals Histerid beetles (HB) were captured, distributed by five genera and 14 species/ morphospecies (species). All species (14 species, 682 individuals) were monitored in the native vegetation (NV), 12 species (513 individuals) in the Mature Secondary succession (MS), 13 species (180 individuals) in Early Secondary succession (ES), 11 species (232 individuals) in Agriculture (Ag) and 13 species (338 individuals) in Pasture $(\mathrm{Pa})$. The most abundant species were Phelister sp1 (302 individuals), Phelister sp4 (257 individuals), Hister sp1 (246 individuals) and Phelister sp2 (184 individuals). These four species represent more than 50 percent of all 
specimens collected. The genera Phelister and Hister were prevalent in all communities, with more 71 percent of all specimens captured (Table 1).

Table 1. Total numbers of Histerid beetles species in the environments different in the Brazilian Amazon. $N V=$ Native Vegetation; $M S=$ Mature Secondary succession $(15$ years of regeneration); $E S=$ Early Secondary succession (5 years of regeneration); $A g$ $=$ Agriculture (Cocoa); $\mathrm{Pa}=$ Pasture. $R=$ Rainy Season; Intermediary Season; $D=$ Dry Season.

\begin{tabular}{|c|c|c|c|c|c|c|c|c|c|c|c|c|c|c|c|c|}
\hline Species & & NV & & & MS & & & ES & & & Ag & & & $\mathbf{P a}$ & & \\
\hline & $\mathbf{R}$ & I & D & $\mathbf{R}$ & I & D & $\mathbf{R}$ & I & D & $\mathbf{R}$ & I & D & $\mathbf{R}$ & I & D & 10 tal \\
\hline $\begin{array}{l}\text { Phelister } \\
\text { haemorrhous }\end{array}$ & 14 & 4 & 6 & - & - & - & & - & - & - & - & - & 6 & 4 & 3 & 37 \\
\hline Phelister sp1 & 60 & 68 & - & 16 & 80 & 11 & 17 & 6 & 3 & - & 6 & 8 & 7 & 20 & - & 302 \\
\hline Phelister sp2 & 26 & 25 & - & 26 & 20 & - & 9 & - & 2 & 3 & 2 & 34 & 7 & 15 & 15 & 184 \\
\hline Phelister sp3 & - & 25 & - & 10 & 72 & 22 & 1 & 2 & 1 & - & 6 & 10 & 10 & 5 & 6 & 170 \\
\hline Phelister sp4 & 28 & 20 & 6 & 35 & 30 & & 2 & 10 & 2 & - & - & 26 & 19 & 20 & 59 & 257 \\
\hline Hister punctifer & 24 & 8 & 7 & 14 & 10 & 3 & 6 & 6 & 7 & 6 & 6 & 5 & 3 & 2 & 1 & 108 \\
\hline Hister $\mathrm{sp} 1$ & 44 & 30 & - & 33 & 38 & 18 & 18 & 6 & - & 9 & 14 & 30 & - & 2 & 3 & 246 \\
\hline Hister $\mathrm{sp} 2$ & 6 & 40 & - & 2 & 2 & 1 & - & - & - & 8 & 1 & 8 & 2 & - & 18 & 88 \\
\hline $\begin{array}{l}\text { Omalodes } \\
\text { marseuli }\end{array}$ & 11 & 8 & 7 & 13 & 2 & 6 & 8 & 2 & 1 & 7 & 3 & 3 & 10 & 4 & 4 & 89 \\
\hline Omalodes sp1 & 72 & 14 & 6 & 2 & - & - & 4 & 8 & 4 & 4 & 4 & 10 & 6 & 2 & 12 & 148 \\
\hline Omalodes sp2 & 30 & 24 & 16 & 10 & 10 & 0 & 1 & - & 8 & - & - & - & 3 & - & 24 & 126 \\
\hline Euspilotus sp1 & 16 & 8 & 8 & 5 & 2 & 1 & 6 & 6 & 5 & 6 & 6 & 2 & 5 & 4 & - & 80 \\
\hline Euspilotus sp2 & 6 & 6 & 4 & 10 & 5 & 4 & 12 & 11 & 7 & 6 & 3 & 1 & 14 & 7 & 7 & 103 \\
\hline Operclipygus $\mathrm{sp}$ & 5 & - & - & - & - & - & 2 & - & - & - & - & - & - & - & - & 7 \\
\hline
\end{tabular}

Histerid beetles (HB) richness and abundance presented significant differences between ecosystems $\left(\mathrm{F}_{4,114}=111.3, \mathrm{p}<0.001 ; \mathrm{F}_{4,114}=346, \mathrm{p}<0.001\right)($ Figs. $2 a$ and $2 b)$. Generally, less disturbed ecosystems had higher values of both indexes, although with exceptions: higher richness and abundance depicted in Pastures when comparing with Cocoa farms (Ag) and Early secondary succession (ES).
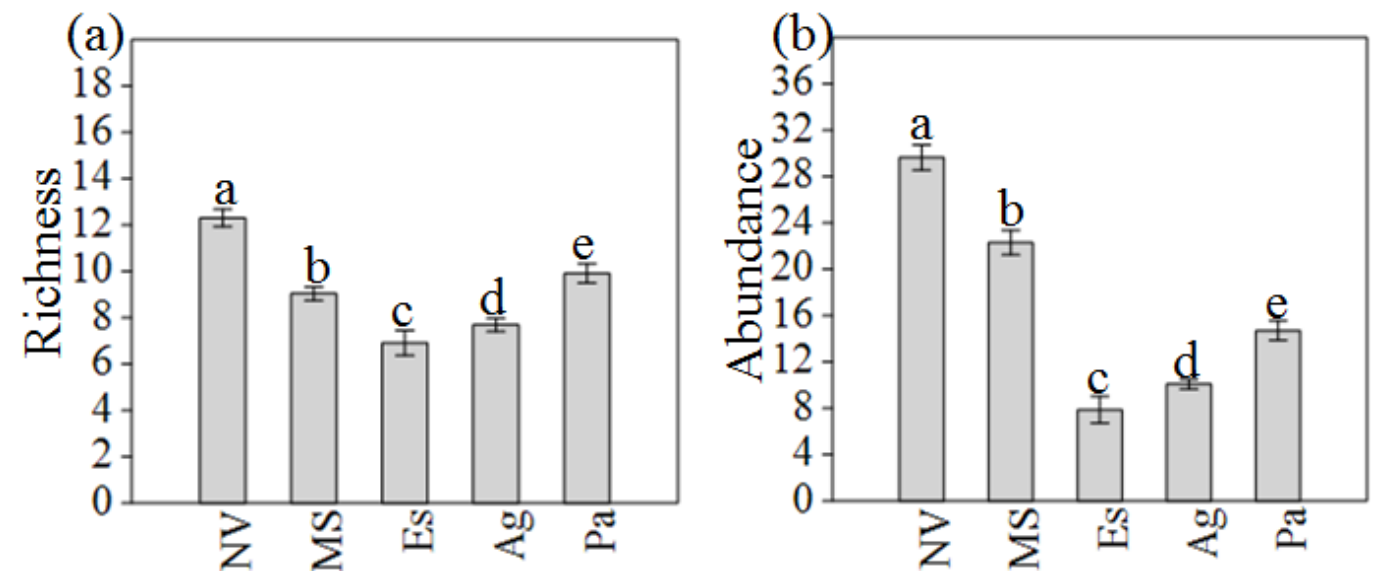

Figure 2. Differences in the projected values for (a) Richness ( $\pm S E$ ), and (b) Abundance $( \pm S E)$ of Histerid beetles $(H B)$ community in the different ecosystems considered. The values followed by the same letters are not significantly different according to Tukey test.

$N V$, Vegetation native; MS, Mature Secondary succession (vegetation with 15 years of regeneration); ES, Early Secondary succession (vegetation with five years of regeneration); Ag, Agriculture; Pa, Pasture. 
NV presented all species while Phelister haemorrhous was not captured in MS, ES and Ag; Operclipygus sp was not captured in MS, Ag and Pa; Hister sp2 and Omalodes $\mathrm{sp} 2$, were not found in ES and Ag, respectively.

The results of the NMDS showed that the HB assemblages of different ecosystems could be separated from each other by ordination of the species composition, suggesting that these assemblages change gradually from the most pristine to more disturbed ecosystems. The composition of the HB of NV and MS were more similar to each other than HB assemblages of other habitats: ES, Ag and Pa could be discriminated from NV and MS (Fig. 3). In fact, the Permutational Multivariate Analysis of Variance (PERMANOVA) showed that HB taxonomic composition of the ecosystems studied was significantly different $\left(\mathrm{F}_{4,114}=28.44, \mathrm{p}<0.0001\right)$.

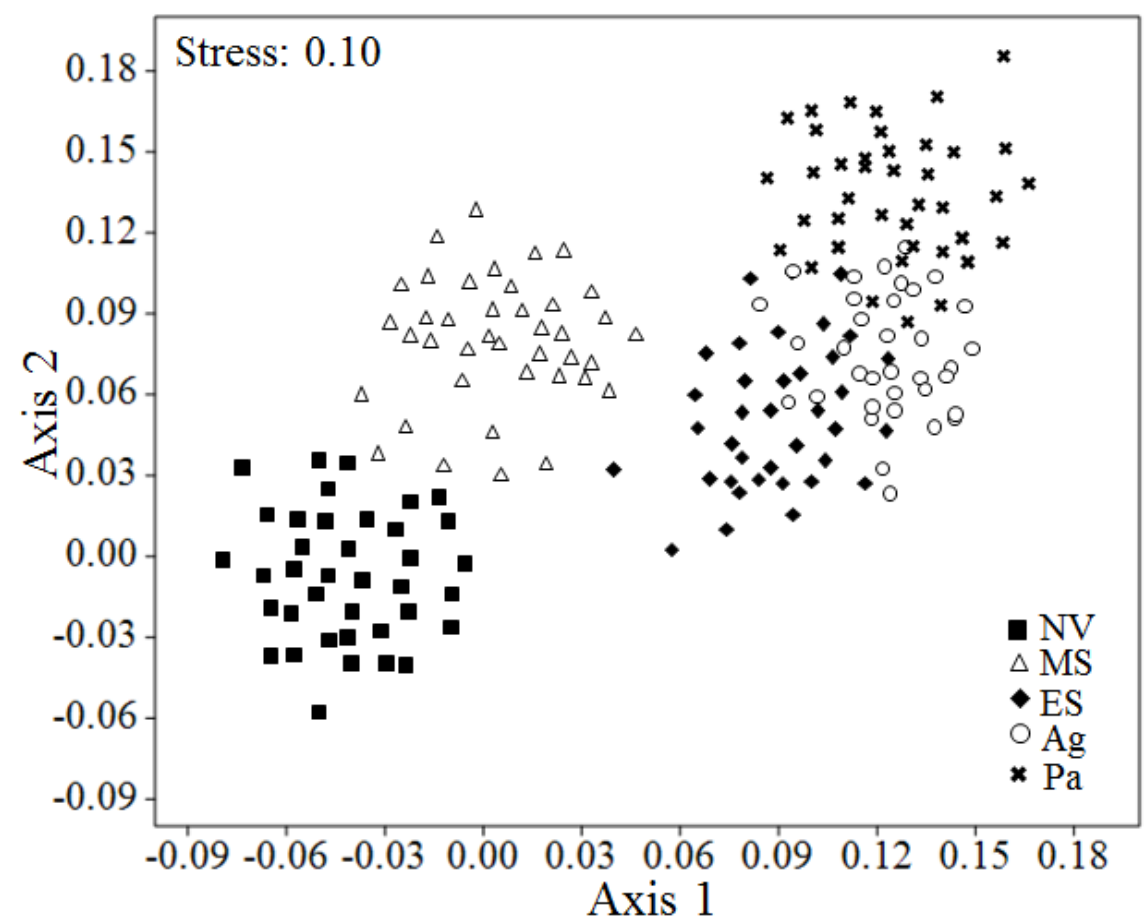

Figure 3. Non-metric multidimensional scaling (NMDS) showing Histerid beetles grouped in accordance with the ecosystems (using Bray-Curtis similarity). NV, Vegetation native; MS, Mature Secondary succession (vegetation with 15 years of regeneration); ES, Early Secondary succession (vegetation with five years of regeneration); Ag, Agriculture (Cocoa); Pa, Pasture.

\section{Seasonality patterns in Histerid beetles assemblages}

With respect to the relation between the period of the year and HB assemblages, statistical differences in abundance and richness were identified $\left(\mathrm{F}_{2,342}=11.71\right.$, $\left.\mathrm{p}<0.001 ; \mathrm{F}_{2,342}=13.29, \mathrm{p}<0.001\right)$ : significant differences in abundance were found between the averages of the rainy and dry seasons (Tuckey test: $Q=6.76, p<0.001$ ), and the intermediary and dry seasons (Tuckey test: $\mathrm{Q}=5.64, \mathrm{p}<0.05$ ); significant differences in richness were found between averages of rainy and intermediary seasons (Tuckey test: $\mathrm{Q}=3.17, \mathrm{p}<0.01$ ), and intermediary and dry seasons (Tuckey test: $\mathrm{Q}=4.09, \mathrm{p}<0.05$ ) (Fig. 4a). 

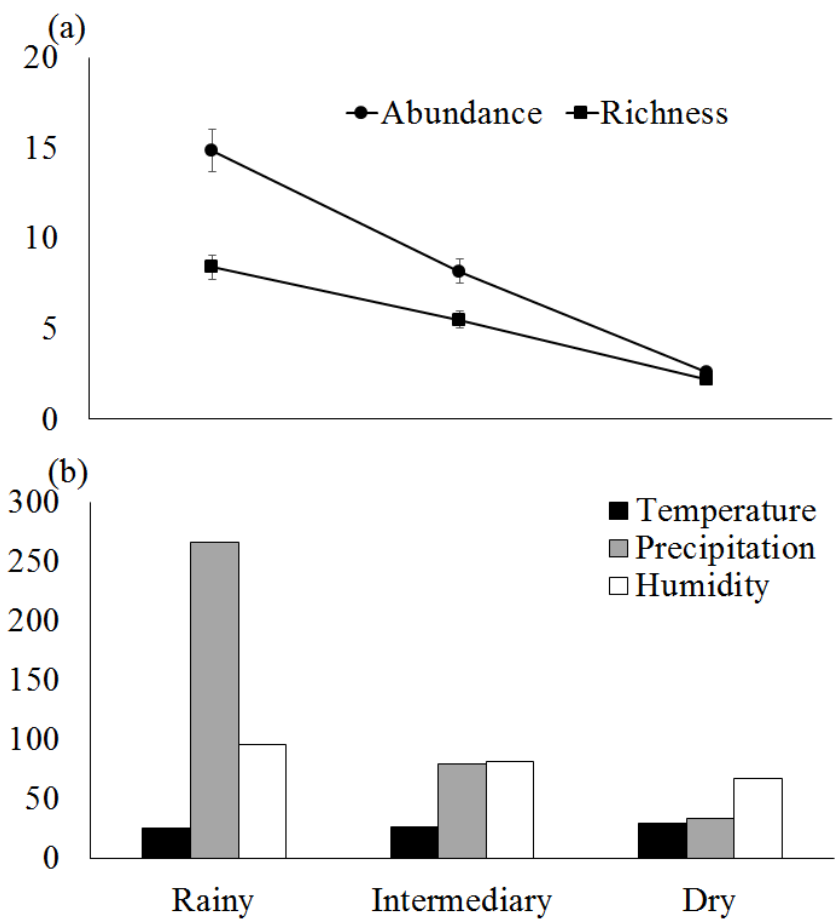

Figure 4. Abundance and richness of Histerid beetles (a) and distribution of environmental variables during the study period $(b)$.

Among the climatic variables evaluated (Figure 4b), humidity and precipitation were positively correlated with the abundance and richness of Histeridae. In contrast, the air temperature negatively influenced these indexes (Table 2).

Table 2. Pearson correlation between environmental variables and ecological indices (abundance and richness) of Histeridae collected in Uruará, Pará, northing Brazil. Asterisks indicate statistical significance at level of $* p<0.05 ; * * p<0.01 ; * * * p<0.001$.

\begin{tabular}{|l|l|l|}
\hline Environmental variables & Abundance & Richness \\
\hline Humidity & $0.57^{* * *}$ & $0.49^{* * *}$ \\
\hline Temperature & $-0.29^{*}$ & $-0.29^{* *}$ \\
\hline Precipitation & $0.48^{* * *}$ & $0.44^{* * *}$ \\
\hline
\end{tabular}

\section{Discussion}

\section{Composition}

Degallier et al. (2011) highlighted the shortage of information on Histerid beetles (HB) in Neotropical areas, where environmental and ecological conditions should enhance their biodiversity. In fact, there is a lack of specific collections and specialized taxonomists for this group. Despite the lack of HB collections, the results obtained provide clues on the diversity of the group in the Amazon region (Leivas et al., 2013).

The genus Phelister (Marseul, 1853), which was the most abundant in the present study, represents a varied genus with 88 species described with mostly Neotropical distribution (Mazur, 2011). These species can be found on diverse substrates like faeces, carcasses, decomposing plants, plants, mammal burrows, bird nests, and in debris piles 
of leaf-cutting ants. Some species, associated with carcasses, have been considered relevant for forensic entomological studies (Almeida and Mise, 2009; Leivas et al., 2013). The enormous diversity, lack of taxonomic studies, and the possibility of description of many new taxa hinders the identification of species (Leivas et al., 2013). The genus Hister (Linnaeus, 1758), which was the second most abundant in the present study, is the most diverse genus of HB, with approximately 195 described species distributed across all zoogeographic regions (Mazur, 2011). These species occur in faeces, carcasses, decomposing plants and fungi, mammal burrows, and in debris piles of leaf-cutting ants. The small number of species recorded in Brazil suggests that new taxa and new records might be described in future (Leivas et al., 2013, 2015).

In the present study, both richness and abundance were the highest in the most pristine and/or conserved ecosystems (e.g. NV and MS). These results suggest the presence of differences among HB communities associated with specific ecosystems, probably related with the environmental conditions and bioecology of species (Moraes et al., 2013). Summerlin (1989) mentions a trend starting from low dominance and high richness of $\mathrm{HB}$ communities in pristine ecosystems to higher abundances and reduced richness of $\mathrm{HB}$ communities in open and degraded ones. Thus, diversity and abundance of $\mathrm{HB}$ communities are intimately related with differences in environmental characteristics of these ecosystems (Lopes et al., 2005).

Biotic and abiotic factors associated with most pristine/ heterogeneous environments, are, for example, mild climates, high canopy cover, and complex ground cover that provide environments for hibernation and more diverse prey, and better conditions for larvae and adults. Cattle treading on pasture areas or the use of machinery in agriculture areas contribute to soil compaction, resulting in changes in the soil structure, reduction of soil litter and water, thereby decreasing and/or eliminating many species (Kruess and Tscharntke, 2002).

\section{Seasonality}

In the present study, the abundance and richness of $\mathrm{HB}$ collected at different times of the year (rainy season, intermediary season, and dry season) depicted a trend with higher diversity during the rainy season, corroborating the hypothesis that the abundance, richness, and diversity are associated with climatic conditions (Andresen, 2005). Nonetheless, microclimatic factors are not necessarily correlated with climatic conditions, but they play an important part in the activity of HB and associated taxa in different climates (Moraes et al., 2013).

The positive correlation between air moisture and the diversity of HB is expected, because higher air moisture may produce favourable microclimates for HB. Previous studies demonstrated that vegetation structure and its effects on microclimate (e.g. temperature and air moisture) might be one of the most important factors controlling and structuring the distribution of beetles (Magura et al., 2000). Apparently, the evolutionary life cycle strategy of beetles is optimized and synchronized with seasonal changes of microclimatic environmental conditions (Kotze et al., 2011; Wang et al., 2014).

Although temperature was negatively correlated with abundance and richness in the present study, annual temperature variation in this region is small, suggesting that rain and humidity are probably the main drivers affecting the dynamics of invertebrates (Andresen, 2008). Silva et al. (2010) presented two hypotheses to explain the lower abundance and richness of adult beetles in the dry season: (1) adults are sensitive to the 
effects of drought and remain underground during this period, or (2) adults die in the dry season and only the immature beetles survive in the nest, reaching the adult stage at the beginning of the wet season. Nevertheless, temperature is a major factor affecting activity, flight, foraging behaviour, and metabolism of beetles (Saska et al., 2010).

Additional studies are necessary to document the extent of sensitivity to microclimate and climate, and they could be particularly relevant in the light of the potential effects of climate change (Williams et al., 2007; Maveety et al., 2014). Understanding seasonal patterns of beetles in a given region is important for several reasons. Firstly, seasonal variations in abundance, richness, and species composition emphasize the role of phenology and the effect of survey timing on the results obtained for studying the association of $\mathrm{HB}$ with ecosystems. Further, seasonal information of HB might be a relevant ecological indicator, which might have importance in the management of ecosystems.

\section{Conclusion}

The Histerid beetles collected in this study demonstrate patterns of habitat preference and marked seasonal variations. In addition, the results indicate factors and conditions that might affect overall biodiversity distribution in the Brazilian Amazon. In fact, the present study should be complemented with studies linking Histerid beetles with other taxa for understanding and assessing the state of conservation of the diverse ecosystems of the studied region.

Acknowledgements. We wish to thank SEMMA/ Uruará for logistics support. We also thank the Lucas Paixão, Edielson Mendes, Ediones Santos and Sidicley Santos for assistance in the field works. This work is supported by: European Investment Funds by FEDER/COMPETE/POCI-Operational Competitiveness and Internationalization Program, under Project POCI-01-0145-FEDER-006958 and National Funds by FCT - Portuguese Foundation for Science and Technology, under the project UID/AGR/04033/2013.

\section{REFERENCES}

[1] Aerts, R., Honnay, O. (2011): Forest restoration, biodiversity and ecosystem functioning. - BMC Ecology 11: 1-10.

[2] Almeida, L. M., Mise, K. M. (2009): Diagnosis and key of the main families and species of South American Coleoptera of forensic importance. - Revista Brasileira de Entomologia 53: 227-244.

[3] Almeida, S. S. P., Louzada, J. N. C. (2009): Estrutura da comunidade de Scarabaeinae (Scarabaeidae: Coleoptera) em fitofisionomias do Cerrado e sua importância para a conservação. - Neotropical Entomology 38: 32-43.

[4] Anderson, M. J. (2001): A new method for non-parametric multivariate analysis of variance. - Austral Ecology 26: 32-46.

[5] Andreasen, J. K., O’Neill, R. V., Noss, R., Slosser, N. C. (2001): Considerations for the development of a terrestrial index of ecological integrity. - Ecological Indicators 1: 2135 .

[6] Andresen, E. (2005): Effects of season and vegetation type on community organization of dung beetles in tropical dry forest. - Biotropica 37: 291-300.

[7] Andresen, E. (2008): Dung beetle assemblange in primary forest and disturbed habitats in a tropical dry forest landscape in western Mexico. - Journal Insect of Conservation 18: 639-650. 
[8] Bicknell, J. E., Phelps, S. P., Davies, R. G., Mann, D. J., Struebig, M. J., Davies, Z. G. (2014): Dung beetles as indicators for rapid impact assessments: Evaluating best practice forestry in the neotropics. - Ecological Indicators 43: 154-161.

[9] Cajaiba, R. L., Cabral, J. A., Santos, M. (2015): A minimal invasive method to forecast the effects of anthropogenic disturbance on tropical cave beetle communities. Neotropical Entomology 4: 1-9.

[10] Cajaiba, R. L., Paixao, L. J., Santos, S. M., Barbosa, I. M., Silva, W. B. (2014): Inventário de araneofauna (Arachnida, Araneae) coletadas em pastagens no município de Uruará, Pará, Brasil. - Biota Amazônia 4: 98-101.

[11] Cajaiba, R. L., Perico, E., Dalzochio, M. S., Silva, W. B., Bastos, R., Cabral, J. A., Santos, M. G. (2017): Does the composition of Scarabaeidae (Coleoptera) communities reflect the extent of land use changes in the Brazilian Amazon? Ecological Indicators 74: 285-294.

[12] Cajaiba, R. L., Perico, E., Silva, W. B., Santos, M. (2017b): Attractiveness of Scarabaeinae (Coleoptera: Scarabaeidae) to different baits in the Brazilian Amazon region. - Revista de Biologia Tropical, v. 65, p. 917-924, 2017.

[13] Cajaiba, R. L., Silva, W. B. (2015): Abundância e Diversidade de Coleoptera (Arthropoda: Insecta) de Solo em Fragmentos de Capoeira ao Entorno da Zona Urbana do Município de Uruará-PA, Brasil. - EntomoBrasilis 8: 30-37.

[14] Cajaiba, R. L., Silva, W. B. (2017): Diversidade e sazonalidade de Cydnidae (Insecta: Hemiptera: Heteroptera) em diferentes habitat no estado do Pará, norte do Brasil. Revista Brasileira de Biociências 15: 32-37.

[15] Campos, R. C., Hernández, M. I. M. (2015): Changes in the dynamics of functional groups in communities of dung beetles in Atlantic forest fragments adjacent to transgenic maize crops. - Ecological Indicators 49: 216-227.

[16] Corrêa, R. C., Moura, D. P., Leivas, F. W. T., Almeida, L. M. (2012): Operclipygus hospes (Lewis) (Coleoptera, Histeridae): a Beetle of Potential Forensic Importance for Buried Bodies. - Neotropical Entomology 41: 254-256.

[17] Degallier, N., Leivas, F. W. T., Moura, D. P. (2011): Histerid beetles of French Guiana. V. Revision of the genus Ebonius Lewis (Coleoptera, Histeridae, Omalodini). - Zootaxa 2824: 44-52.

[18] Godfray, H. C. J., Lewis, O. T., Memmott, J. (1999): Studying insect diversity in the tropics. - Philosophical Transactions of the Royal Society B 354: 1811-1824.

[19] Hassan, R., Scholes, R., Ash, N. (2005): Ecosystems and Human Well-Being: Current State and Trends, vol. 1. - New York, Island Press.

[20] Kotze, D. J., Brandmayr, P., Casale, A. (2011): Forty years of carabid beetle research in Europe - from taxonomy, biology, ecology and population studies to bioindication, habit.at assessment and conservation. - Zookeys 100: 55-148.

[21] Kruess, A., Tscharntke, T. (2002): Contrasting responses of plant and insect diversity to variation in grazing intensity. - Biological Conservation 106: 293-302.

[22] Leivas, F. W. T., Bicho, C. L., Degallier, N., Moura, D. P. (2012a): Revision of the genus Scapomegas Lacordaire, 1854 (Coleoptera: Histeridae: Omalodini). - Zootaxa 3482: 3346.

[23] Leivas, F. W. T., Grossi, P. C., Almeida, L. M. (2013): Histerídeos (Staphyliniformia: Coleoptera: Histeridae) dos Campos Gerais, Paraná, Brasil. - Biota Neotropical 13: 196204.

[24] Leivas, F. W. T., Mise, K. M., Almeida, L. M., Macari, B. P., Gomy, Y. (2012b): New species and key of Aeletes Horn (Coleoptera: Histeridae: Abraeinae) from Brazil. Zootaxa 3165: 63-68.

[25] Leivas, F. W. T., Moura, D. P., Caterino, M. S. (2015): Brazilian Histerini (Coleoptera, Histeridae, Histerinae): a new species, key to the genera, and checklist of species. Zootaxa 3941: 437-444. 
[26] Lopes, P. P., Louzada, J. N. C., Oliveira-Rebouças, P. L., Nascimento, L. M., SantanaReis, V. P. G. (2005): Resposta da Comunidade de Histeridae (Coleoptera) a Diferentes Fisionomias da Vegetação de Restingas no Espírito Santo. - Neotropical Entomology 34: 025-031.

[27] Magura, T., Tóthmérész, B., Bordán, Z. (2000): Effects of nature management practice on carabid assemblages (Coleoptera: Carabidae) in a non-native plantation. - Biological Conservation 93: 95-102.

[28] Marinoni, R. C. (2001): Os grupos tróficos em Coleoptera. - Revista Brasileira de Zoologia 18: 205-224.

[29] Maveety, S. A., Browne, R. A., Erwin, T. L. (2014): Carabid beetle diversity and community composition as related to altitude and seasonality in Andean forests. - Studies on Neotropical Fauna and Environmental 48: 165-174.

[30] Mazur, S. (2011): A concise catalogue of the Histeridae (Insecta: Coleoptera). Warsaw University of Science - SGGW Press, Warsaw, p.1-332.

[31] Moraes, R. M., Mendonça Jr, Ott, R. (2013): Carabid beetle assemblages in three environments in the Araucaria humid forest of Southern Brazil. - Revista Brasileira de Entomologia 57: 67-74.

[32] Morris, R. J. (2010): Anthropogenic impacts on tropical forest biodiversity: a network structure and ecosystem functioning perspective. - Philosophical Transactions of the Royal Society B 365: 3709-3718.

[33] Nichols, E., Spector, S., Louzada, J., Larsen, T., Amezquita, S., Favila, M. E. (2008): Ecological functions and ecosystem services provided by Scarabaeinae dung beetles. Biological Conservation 141: 1461-1474.

[34] Paoletti, M. G., D'inca, A., Tonin, E., Tonon, S., Migliorini, C., Petruzzelli, G., Pezzarossa, B., Gomiero, T., Sommaggio, D. (2010): Soil invertebrates as bio-indicators in a natural area converted from agricultural use: the case study of VallevecchiaLugugnana in north-eastern Italy. - Journal of Sustainable Agriculture 34: 38-56.

[35] Saska, P., Martinkova, Z., Honek, A. (2010): Temperature and rate of seed consumption by ground beetles (Carabidae). - Biology Control 52: 91-95.

[36] Silva, R. J., Diniz, S., Vaz-de-Mello, F. Z. (2010): Heterogeneidade do habitat, riqueza e estrutura da assembleia de besouros rola-bostas (Scarabaeidae: Scarabaeinae) em áreas de cerrado na Chapada dos Parecis, MT. - Neotropical Entomology 39: 934-941.

[37] Summerlin, J. W. (1989): Techniques for collecting, rearing and handling histerid beetles. - Southwestern Entomology 14: 127-132.

[38] Turner, B. L. I., Lambin, E. F., Reenberg, A. (2007): The emergence of land change science for global environmental change and sustainability. - Proceedings of the National Academy of Sciences 104: 20666-20671.

[39] Vasquez-Velez, L. M., Bermudez, C., Chacon, P., Lozano-Zambrano, F. H. (2010): Analysis of the richness of Staphylinidae (Coleoptera) on different scales of a subAndean rural landscape in Colombia. - Biodiversity Conservation 19: 1917-1931.

[40] Viana, V. M., Pinheiro, L. V. (1988): Conservação da biodiversidade em fragmentos florestais. - IPEF 32: 25-42.

[41] Viegas, G., Stenert, C., Schulz, U. H., Maltchik, L. (2014): Dung beetle communities as biological indicators of riparian forest widths in southern Brazil. - Ecological Indicators 36: 703-710.

[42] Wang, X., Müller, J., An, L., Ji, L., Liu, Y., Wang, X., Hao, Z. (2014): Intra-annual variations in abundance and species composition of carabid beetles in a temperate forest in Northeast China. - Journal Insect of Conservation 18: 85-98.

[43] Williams, J. W., Jackson, S. T., Kutzbach, J. E. (2007): Projected distributions of novel and disappearing climates by 2100 AD. - PNAS 104: 5738-5742. 